\title{
Three Rivers: privilege re-assessed
}

\author{
by David Willink
}

In the latest episode in the BCCI saga, the recent House of Lords' decision on legal professional privilege (Three Rivers District Council v Bank of England (No 6) [2004] UKHL 48) is a welcome restoration of orthodoxy in relation to legal advice privilege. But the House declined to address wider concerns raised by an earlier decision of the Court of Appeal, and foreshadowed further judicial reassessment of the scope and justification of litigation privilege.

\section{LEGAL PROFESSIONAL PRIVILEGE}

\section{Scope: litigation and legal advice}

The modern case law on legal professional privilege has divided the privilege into two categories:

(a) litigation privilege, protecting confidential communications - between lawyers, clients and third parties - made for the purposes of litigation; and

(b) legal advice privilege, protecting confidential communications between lawyers and their clients whereby legal advice, whether connected with litigation or not, is sought or given.

For the scope of litigation privilege, the meaning to be attached to 'litigation' is key. The House of Lords has already made clear that litigation in this context does not extend to non-adversarial proceedings, such as care proceedings (re L (A Minor) (Police Investigation: Privilege) [1997] AC 16). Likewise, for the scope of legal advice privilege, the meaning to be attached to 'legal advice' is key. The authorities have been reviewed and summarised thus: "legal advice is not confined to telling the client the law; it must include advice as to what should prudently and sensibly be done in the relevant legal context" (Balabel v Air India [1988] Ch 317, 330 per Taylor LJ).

\section{Nature: an absolute guarantee of confidentiality}

Privilege recognises the public interest in a person's being able to consult a legal adviser in absolute confidence. The effect of a successful claim of privilege is stark. Subject only to waiver by the client, or express ousting by statute (cf $R$ (Morgan Grenfell Ltd) v Special Commissioner of Income Tax [2003] 1 AC 563), the privilege is absolute. As Lord Reid noted in Duke of Argyll v Duchess of Argyll (1962 SC (HL) 88): "the effect, and indeed the purpose, of the law of confidentiality is to prevent the court from ascertaining the truth so far as regards those matters which the law holds to be confidential."

But this could give the impression that privilege is simply a rule of evidence - permitting or requiring the withholding of certain material from one's opponent and the court. But it has a greater significance. In $R \mathrm{v}$ Derby Magistrates' Court, ex parte B [1996] AC 487, Lord Taylor of Gosforth CJ said:
"Legal professional privilege is thus much more than an ordinary rule of evidence, limited in its application to the facts of a particular case. It is a fundamental condition on which the administration of justice as a whole rests."

Similarly, in $R$ (Morgan Grenfell \& Co Ltd) v Special Commissioner of Income Tax [2003] 1 AC 563-Lord Hoffmann described legal professional privilege as: "a fundamental human right long established in the common law."

Of course, there is plainly a competing public interest in keeping privilege within proper bounds. Nevertheless, it is no part of a court's role to weigh the claim of privilege in any particular case against another public interest, such as the public interest in a fair trial. As Lord Taylor noted in $R$ v Derby Magistrates Court, ex parte B [1996] AC 487:

"If a balancing exercise were ever required in the case of legal professional privilege, it was performed once and for all in the sixteenth century, and since then has applied across the board in every case, irrespective of the client's individual merits."

This means that litigation which sets the bounds of privilege by defining the balance between these competing public interests assumes a particular importance. And within that litigation, the underlying policy justification for the privilege itself assumes a particular importance, because it is the weight of that justification that will determine where the balance lies. The difference between the Court of Appeal and the House of Lords in the present 
case is reducible to differing views of this policy justification.

\section{THREE RIVERS: BACKGROUND TO THE DISCLOSURE LITIGATION}

The factual background to the Three Rivers litigation should, by now, need little rehearsal. Following the collapse of BCCI in July 1991 and the subsequent Bingham Inquiry into the Bank of England's supervision of BCCI, the claimants (creditors of BCCI) are seeking redress from the Bank of England ("the Bank"). In order to establish liability for misfeasance in public office, the claimants must establish that the collapse of BCCI is attributable to acts or omissions of the Bank "in bad faith" (s 1(4) Banking Act 1987). Accordingly, they sought disclosure of large numbers of documents relating to the Bingham Inquiry from the Bank; and the present satellite litigation arose from the Bank's resistance to that disclosure on the grounds of privilege.

As there was never any suggestion that the Bingham Inquiry was anything other than inquisitorial, the Bank made no claim to resist disclosure based on litigation privilege; its resistance to disclosure was based solely on legal advice privilege. This presented the courts with two questions on the scope of legal advice privilege:

(a) who was the client of the legal advisers advising the Bank?

(b) was their advice 'legal advice' for the purposes of privilege?

The first of these was addressed in Three Rivers (No 5); the second in Three Rivers (No 6).

\section{THREE RIVERS (NO 5): IN THE HIGH COURT}

For the purposes of co-ordinating its contribution to the Bingham Inquiry, the Bank of England had set up a small internal group - the Bingham Inquiry Unit (BIU). The Bank had also engaged Freshfields solicitors, and counsel, to advise on all its dealings in relation to the Bingham Inquiry.

The claimants first sought disclosure of documents created by Bank employees, and ex-employees, for the purpose of being passed by the BIU to Freshfields. Three Rivers District Council v Governor and Company of the Bank of England (No 5) [2002] EWHC 2730, Tomlinson J described these documents (in para [10]) as:

“... generated for the purpose of providing information to the Bank's legal advisers to enable them to prepare submissions and/or to advise on the nature, presentation, timing and/or content of the Bank's submissions to, evidence for and responses to requests from the inquiry."

He held that: "an internal confidential document, not being a communication with a third party, which was produced or brought into existence with the dominant purpose that it or its contents be used to obtain legal advice is privileged from production."

In a subsequent addendum to his judgment, he held that documents prepared by ex-employees and ex-officers of the Bank stood on the same footing, for legal advice privilege purposes, as documents prepared by current employees and officers.

\section{THREE RIVERS (NO 5): IN THE COURT OF APPEAL}

The claimants appealed against the High Court decision, and the Court of Appeal allowed the appeal ([2003] QB 1556). It concluded that legal advice privilege only protected communications between lawyer and client, not lawyer and third party; and that Freshfields' client for these purposes was the BIU, and no-one else. Documents originating anywhere in the Bank other than the BIU, even if they were brought into existence with a view to their communication to Freshfields, were not subject to legal advice privilege. This conclusion was determinative of the appeal.

Although not necessary for its decision, and despite not having heard specific argument addressed to it on the point, the Court of Appeal then went further. It also indicated that the material in question was anyway prepared "for the dominant purpose of putting relevant factual material before the inquiry in an orderly and attractive fashion, not for the dominant purpose of taking legal advice upon such material”, and so could not, by its nature, attract legal advice privilege (see para [37]).

The Bank was refused permission to appeal to the House of Lords, and the process of disclosure in accordance with the Court of Appeal's judgment commenced. But the Bank still refused to disclose:

(a) any communications between the BIU and Freshfields, or

(b) any material relating to the preparation of the overarching statement that had been submitted to the inquiry on behalf of the Bank.

This refusal was on two grounds. First, the claimants had told the Court of Appeal that they were not seeking disclosure of any communications between the BIU and Freshfields, as it was accepted that they were covered by legal advice privilege. Secondly, the Bank argued that "legal advice" in the Court of Appeal's declaration should be interpreted widely so as to cover all advice and assistance from Freshfields or counsel relating to the evidence to be submitted and the submissions to be made to the inquiry on behalf of the Bank. This advice became labelled as "presentational advice”. 


\section{THREE RIVERS (NO 6): IN THE HIGH COURT}

In the light of the obiter comments in the earlier Court of Appeal judgment, and despite the claimants' earlier assurances in the Court of Appeal that they were not seeking its disclosure, the claimants went before Tomlinson J again to obtain discovery of the 'presentational advice' material.

In Three Rivers District Council v Governor and Company of the Bank of England (No 6) [2003] EWHC 2565, he held that the rationale of the Court of Appeal judgment in Three Rivers (No 5) was that the seeking or giving of advice for presentational purposes should not in general be categorised as legal advice of the sort which attracted privilege. He felt constrained to order that the only documents or parts of documents that the Bank was entitled to withhold were those passing between the BIU and Freshfields for the purpose of seeking or obtaining “advice concerning the Bank's rights and obligations".

\section{THREE RIVERS (NO 6): IN THE COURT OF APPEAL}

The Bank appealed against this narrow interpretation of "legal advice". On March 1, 2004 the Court of Appeal dismissed the appeal (Three Rivers District Council v Governor and Company of the Bank of England (No 6) [2004] QB 916). Giving the judgment of the court, Lord Phillips MR did agree with the Bank that the Court of Appeal's earlier decision did not constrain Tomlinson $\mathrm{J}$ in the way he thought he was constrained. However, the Court then concluded its own consideration of the concept of "legal advice" by agreeing that for these purposes, it was to be narrowly construed as being restricted to advice concerning the client's legal rights and obligations such as are capable of being the subject of litigation.

This was essentially a policy decision, but one which found support in some authorities. Lord Brougham LC, in Greenough v Gaskell (1833) 1 My \& K 98, had explained the reason for legal advice privilege:

"a person at times requires the aid of professional advice upon the subject of his rights and liabilities, with no reference to any particular litigation, and without any other reference to litigation generally than all human affairs have, in so far as every transaction may, by possibility, become the subject of judicial inquiry."

In Wheeler v Le Marchant (1881) 17 Ch D 675, Sir George Jessel MR had said:

"The protection [afforded by privilege] is of a very limited character, and in this country is restricted to the obtaining the assistance of lawyers, as regards the conduct of litigation of the rights to property."

The court examined the authorities relied on by the Bank, and said (at para [25]):
"All of the cases to which we have been thus far referred were ones in which the relationship of client and solicitor arose in relation to transactions involving legal rights and obligations capable of becoming the subject matter of litigation. We have been referred to no case in which legal advice privilege has been established where this was not the case."

The court also prayed in aid the 1967 Report of the Law Reform Committee on Privilege in Civil Proceedings. That had described legal advice privilege as "a privilege in aid of litigation", and continued:

"19. What distinguishes legal advice from other kinds of professional advice is that it is concerned exclusively with rights and liabilities enforceable in law, ie in the ultimate resort by litigation in the courts or in some administrative tribunal. It is, of course, true that on many matters on which a client consults his solicitor he does not expect litigation and certainly hopes that it will not occur; but there would be no need for him to consult his solicitor to obtain legal advice unless there were some risk of litigation in the future in connection with the matter upon which advice is sought. As Lord Brougham pointed out, it is to minimise that risk by ensuring that he so conducts his affairs as to make it reasonably certain that he would succeed in any litigation which might be brought in connection with them, that the client consults his solicitor at all."

For its policy decision to take a restrictive view of legal advice, the court drew support from the analysis of Taylor LJ in Balabel. Taylor LJ had said:

"... those dicta in the decided cases which appear to extend privilege without limit to all solicitor and client communications upon matters within the ordinary business of a solicitor and referable to that relationship are too wide. It may be that the broad terms used in the earlier cases reflect the restricted range of solicitors' activities at the time. Their role would then have been confined for the most part to that of lawyer and would not have extended to business adviser or man of affairs. To speak therefore of matters 'within the ordinary business of a solicitor' would in practice usually have meant the giving of advice and assistance of a specifically legal nature. But the range of assistance given by solicitors to their clients and of activities carried out on their behalf has greatly broadened in recent times and is still developing. Hence the need to re-examine the scope of legal professional privilege and keep it within justifiable bounds. ([1988] Ch 317 , 331-2).”

This passage was accepted by counsel for both sides in the House of Lords as "at best, an over-simplification": see Lord Rodger of Earlsferry at para [58]. To this, the Court of Appeal added (at para [30]):

"We agree with this observation of Taylor LJ to the effect that in circumstances where the traditional role of a solicitor has expanded, it is necessary to keep legal professional privilege within justifiable bounds. The fact the work done is within what may be the ordinary business of a solicitor does not 
necessarily mean that it attracts privilege. This case raises the question of the scope of the 'justifiable bounds'."

The court drew a bright-line distinction (at para [26]):

“... where a solicitor-client relationship is formed for the purpose of obtaining advice or assistance in relation to rights and liabilities, broad protection will be given to communications passing between solicitor and client in the course of that relationship. ... We do not consider that the same principle applies to communications between solicitor and client when the dominant purpose is not the obtaining of advice and assistance in relation to legal rights and obligations."

The court described its decision not in terms of a limitation on legal advice privilege, but as a refusal to extend it (paras [36]-[37]). However, Lord Phillips MR concluded with the following observations (at para [39]):

"We have found this area of law not merely difficult but unsatisfactory. The justification for litigation privilege is readily understood. Where, however, litigation is not anticipated it is not easy to see why communications with a solicitor should be privileged. Legal advice privilege attaches to matters such as the conveyance of real property or the drawing up of a will. It is not clear why it should. There would seem little reason to fear that, if privilege were not available in such circumstances, communications between solicitor and client would be inhibited. Nearly fifty years have passed since the Law Reform Committee looked at this area. It is perhaps time for it to receive a further review."

Clearly, then, the court's instinct was not only that any extension of legal advice privilege should be resisted. It felt that the balance of interests between the public interest in a fair trial and the public interest in confidential legal advice should swing in favour of the former by restricting legal advice privilege.

\section{THREE RIVERS (NO 6): IN THE HOUSE OF LORDS}

\section{Introduction}

The Court of Appeal's decision was a narrow one, on the single issue of the meaning of "legal advice". However, the decision - including Lord Phillips MR's dicta quoted above - occasioned wide concern among the legal and governmental communities. This was so, even though the foundations for the decision clearly lay in the earlier Court of Appeal decision in Three Rivers (No 5). Because of this wide concern, the Government (through the Attorney General), the Bar Council and the Law Society were all given leave to intervene in the appeal to the House of Lords by written submissions.

For the Bank's part, it argued its case on two bases. First, it argued that the Court of Appeal was wrong to define the scope of legal advice privilege as narrowly as it did. Secondly, it argued that its communications with Freshfields in relation to "presentational advice" fell within even the narrow definition of 'legal advice' put forward by the Court of Appeal.

For the interveners' part, they too expressed concern at the narrowness of the scope of "legal advice" as set out by the Court of Appeal. They also invited the House of Lords to clarify, following the earlier decision in Three Rivers (No 5), the approach that should be taken to determine whether a communication by an employee to his employer's legal advisers was from the client or from a third party.

The Government also expressed concern on two further counts. The first related to the effectiveness of inquiries. It is widely recognised that inquiries, which are becoming more prevalent, are more effective if those giving evidence to them have the benefit of legal advice (see, for example, the "Salmon principles", set out in the Report of the Royal Commission on Tribunals of Inquiry, 1966, chaired by Salmon LJ (Cmnd 3121)). This is so, even if the inquiry will not have any consequence for the witness's legal rights and obligations, although in the absence of such consequence, and if the Court of Appeal's narrow definition of 'legal advice' were to prevail, a witness's communications with his lawyer concerning his evidence would not be privileged. This would be likely to deter the seeking of legal advice by potential witnesses to inquiries, with a deleterious impact on their effectiveness.

The second concern related to the Government's position as a consumer of legal services, from both employed and independent legal advisers. The legal advice it receives may often be on the rights and obligations of the citizen (either in general or in a particular case), rather than those of the Government; and legal advice plays an important role in both the policy-making and legislative processes - where, by definition, the rights and obligations of the Government, being not yet created, are not engaged. The public interest in the Government's receiving confidential legal advice - both on policy development and in non-justiciable matters such as international affairs - is well established.

On July 29, 2004, after only some 10 minutes' deliberation following the end of counsels' speeches, their Lordships announced that they would allow the Bank's appeal. Reasons were given on November 11, 2004, with substantial speeches being given by Lord Scott of Foscote, Lord Rodger of Earlsferry and Lord Carswell.

\section{Policy justification for legal advice privilege}

Confidential communications arise in many circumstances - doctor and patient; accountant and client; priest and penitent. There is a public interest in these communications remaining confidential. However, it will usually be outweighed by a stronger public interest in the administration of justice, that criminal trials should convict the guilty and acquit the innocent; that civil trials should allow recovery where the claimant is entitled to it, and not 
otherwise. What is distinctive about confidential communications between a lawyer and client, where no litigation is pending or contemplated, which makes them different?

The Court of Appeal's answer to this question had been: even where no litigation is pending or contemplated, litigation may later arise; and it would be wrong for the client's position in that litigation to be prejudiced by the disclosure of earlier communications with his lawyer. Thus, it concluded, there was no justification for the rule if the communications with his lawyer concerned a matter that could not form the basis of litigation.

The House of Lords rejected this narrow policy justification. But it is not immediately apparent that domestic authority alone could conclusively establish a wider base. In $R$ v Derby Magistrates' Court, ex parte B Lord Taylor of Gosforth CJ said:

"In Balabel v Air India [1988] Ch 317 the basic principle justifying legal professional privilege was again said to be that a client should be able to obtain legal advice in confidence.

The principle which runs through all these cases ... is that a man must be able to consult his lawyer in confidence, since otherwise he might hold back half the truth. The client must be sure that what he tells his lawyer in confidence will never be revealed without his consent ( 5 507).”

In $R$ (Morgan Grenfell Ltd) v Special Commissioner of Income Tax Lord Hoffmann referred to legal professional privilege as "a necessary corollary of the right of any person to obtain skilled advice about the law' and continued (p 607):

"Such advice cannot be effectively obtained unless the client is able to put all the facts before the adviser without fear that they may afterwards be disclosed and used to his prejudice."

And in B v Auckland District Law Society [2003] 2 AC 736Lord Millett justified legal professional privilege on the ground that

“... a lawyer must be able to give his client an absolute and unqualified assurance that whatever the client tells him in confidence will never be disclosed without his consent."

However, these statements of principle focus on a relatively narrow, private right and benefit of confidential legal advice to be gained through the application of privilege. There is nothing in them to explain why they cease to be true if, for example, "lawyer" is replaced with “doctor”, mutatis mutandis.

Lord Scott found a broader policy explanation in cases from other jurisdictions. In Upjohn Co v United States (1981) 449 US 383, a decision of the US Supreme Court, Justice Rehnquist said that the purpose of legal professional privilege was:

“... to encourage full and frank communication between attorneys and their clients and thereby promote broader public interests in the observance of law and administration of justice."

Justice Rehnquist went on:

"The privilege recognises that sound legal advice or advocacy serves public ends and that such advice or advocacy depends upon the lawyer being fully informed by the client."

Leading cases in Australia and New Zealand justify the rule on a broader policy basis than merely the need to ensure candour, and most clearly emphasise the social context. For example, in Baker v Campbell (1983) 153 CLR 52, a decision of the High Court of Australia, Murphy J commented that:

"The client's legal privilege is essential for the orderly and dignified conduct of individual affairs in a social atmosphere which is being poisoned by official and unofficial eavesdropping and other invasions of privacy,"

and Wilson J said:

"In fostering the confidential relationship in which legal advice is given and received the common law is serving the ends of justice because it is facilitating the orderly arrangement of the client's affairs as a member of the community."

Finally, the concept of legal professional privilege has been absorbed into the jurisprudence of the European Court of Justice, where in A $M$ \& S Europe Ltd $v$ European Commission [1983] QB 878 Slynn A-G said:

"[The privilege] springs essentially from the basic need of a man in a civilised society to be able to turn to his lawyer for advice and help, and if proceedings begin, for representation; it springs no less from the advantages to a society which evolves complex law reaching into all the business affairs of persons, real and legal, that they should be able to know what they can do under the law, what is forbidden, where they must tread circumspectly, where they run risks."

Lord Rodger of Earlsferry cited a passage from Sir George Mackenzie's Works, Volume 2 (1755) which hints at the wider social context, while still drawing parallels with other recipients of confidences:

"An Advocate is by the Nature of his Imployment tied to the same Faithfulness that any Depositor is: For his Client has depositate in his Breast his greatest Secrets; and it is the Interest of the Common-wealth, to have that Freedom allowed and secured without which Men cannot manage their Affairs and private Business: And who would use that Freedom if they might be ensnared by it?"

Lord Rodger added (at para [54]):

"... the public interest justification for the privilege is the same today as it was 350 years ago: it does not change, or need to change, because it is rooted in an aspect of human nature which does not change either." 
At paragraph [34], Lord Scott of Foscote endorsed this wider policy justification for privilege, in a paragraph worth quoting in its entirety:

"None of these judicial dicta tie the justification for legal advice privilege to the conduct of litigation. They recognise that in the complex world in which we live there are a multitude of reasons why individuals, whether humble or powerful, or corporations, whether large or small, may need to seek the advice or assistance of lawyers in connection with their affairs; they recognise that the seeking and giving of this advice so that the clients may achieve an orderly arrangement of their affairs is strongly in the public interest; they recognise that in order for the advice to bring about that desirable result it is essential that the full and complete facts are placed before the lawyers who are to give it; and they recognise that unless the clients can be assured that what they tell their lawyers will not be disclosed by the lawyers without their (the clients') consent, there will be cases in which the requisite candour will be absent. It is obviously true that in very many cases clients would have no inhibitions in providing their lawyers with all the facts and information the lawyers might need whether or not there were the absolute assurance of nondisclosure that the present law of privilege provides. But the dicta to which I have referred all have in common the idea that it is necessary in our society, a society in which the restraining and controlling framework is built upon a belief in the rule of law, that communications between clients and lawyers, whereby the clients are hoping for the assistance of the lawyers' legal skills in the management of their (the clients') affairs, should be secure against the possibility of any scrutiny from others, whether the police, the executive, business competitors, inquisitive busy-bodies or anyone else (see also paras 15.8 to 15.10 of Adrian Zuckerman's Civil Procedure where the author refers to the rationale underlying legal advice privilege as 'the rule of law rationale'). I, for my part, subscribe to this idea. It justifies, in my opinion, the retention of legal advice privilege in our law, notwithstanding that as a result cases may sometimes have to be decided in ignorance of relevant probative material."

That being the case, the scope of legal advice privilege must reflect the policy reasons that justify the rule.

\section{Scope of legal advice privilege}

The House of Lords held that the scope as identified by the Court of Appeal failed to reflect this policy justification.

In narrow terms, the Court of Appeal had based its conclusions on the absence of cited cases where private rights and obligations were not engaged. However, it was conceded for the claimants that no principled line could be drawn between private law and public law rights and obligations for this purpose. And that, Lord Scott found, was sufficient to determine the appeal; for as far as the Bank was concerned, public law rights and obligations were engaged on two distinct levels. First, the Bingham Inquiry was to examine whether the Bank had properly discharged its public law duties of supervision imposed by the Banking Acts. Second, the inquiry itself was subject to judicial review; and as Lord Scott noted, it would be absurd if privilege were not to attach to advice taken in order to prevent criticism by the inquiry, given that (as is not in doubt) it would attach to advice taken on whether such criticism, once made, were susceptible to public law challenge.

In broader terms, Lord Scott returned to the formulation of Taylor LJ in Balabel, that legal advice "must include advice as to what should prudently and sensibly be done in the relevant legal context." While emphasising that there must be a "relevant legal context" for privilege to attach (that is, dealings with a solicitor as a "man of business" will not attract privilege), he then set out how a communication is to be identified as privileged:

"There is, in my opinion, no way of avoiding difficulty in deciding in marginal cases whether the seeking of advice from or the giving of advice by lawyers does or does not take place in a relevant legal context so as to attract legal advice privilege. In cases of doubt the judge called upon to make the decision should ask whether the advice relates to the rights, liabilities, obligations or remedies of the client either under private law or under public law. If it does not, then, in my opinion, legal advice privilege would not apply. If it does so relate then, in my opinion, the judge should ask himself whether the communication falls within the policy underlying the justification for legal advice privilege in our law. Is the occasion on which the communication takes place and is the purpose for which it takes place such as to make it reasonable to expect the privilege to apply? The criterion must, in my opinion, be an objective one (para [38]).”

He held (at para [43]) that the present case was not in the least marginal; "the presentational advice falls, in my opinion, squarely within the policy reasons underlying legal advice privilege."

However, he also gave examples where, he said, the "relevant legal context" was "clear", or "unmistakable", but which, with respect, would seem to fail the in limine test by falling outside the category of advice relating to "the rights, liabilities, obligations or remedies of the client either under private law or under public law". These include advice given by lawyers to the promoters and opponents of private legislation, and to the Government in relation to the preparation of public bills. Other examples could be given, such as where the advice concerned the rights, liabilities, obligations or remedies of someone other than the client (such as the client's child, or potential beneficiaries under the client's will). Lord Rodger also pointed to the difficulty of accurately characterising advice on criminal matters as relating, strictly speaking, to rights and obligations of the client.

Rather than propounding a further, broader definition which would capture these and other examples, it may be more convenient to leave the Balabel test of "relevant legal 
context" undefined, while using the examples given by Lord Scott to indicate that the concept is not to be narrowly applied.

\section{Did Freshfields' advice meet the Court of Appeal test?}

Because of the conclusions the House reached on the scope of privilege, it was not strictly necessary to consider the Bank's second submission, that the test propounded by the Court of Appeal, narrow though it be, nevertheless covered the advice given by Freshfields. Lord Carswell considered that the advice given did, indeed, relate to the Bank's legal position. He noted that the Bank was potentially liable in both private and public law for the performance of its functions, and said (at para [80]):

"The focus of the inquiry was always going to be a critical examination of the Bank's performance of its supervisory duties under the Banking Acts. It was apparent that some would seek to attach blame to the Bank for failing to take earlier action - the then Prime Minister stated in the House of Commons that the inquiry would 'determine where the blame lies' - and that public criticism in the inquiry report of the conduct of some officials was a distinct possibility. Nor could one rule out the possibility that some amendment, which might be unwelcome to the Bank, of its regulatory powers and duties might be recommended."

He concluded that Tomlinson J, at first instance, had been right to say:

"Anything that the Bank did and said in relation to the inquiry was potentially of great legal sensitivity. It was an inquiry one outcome of which could be criticism of the conduct of the Bank from an informed and highly authoritative source, an outcome which would not only be of some importance in relation to the Bank's ongoing regulatory and supervisory role but would itself be likely either to lead to or to encourage the institution or attempted institution of proceeding against the Bank by depositors and others who had lost money in consequence of the collapse of BCCI" (para [7]).

There is a further, and more general, question to be asked, of interest to those participating in inquiries where there is no question of liability but a real danger of damage to reputation. In these circumstances, the advice and assistance of lawyers are still recognised as being beneficial (see the "Salmon principles" mentioned above); but are the communications in the seeking and giving of such legal advice privileged? The Court of Appeal left this open. Having asked (para [32]):

'Is reputation to be equated with legal rights and obligations so that the advice of a solicitor for the purpose of protecting reputation attracts legal advice privilege?'

the court found it unnecessary to answer the question on the facts of the case, as the court thought it "questionable as to whether our private law affords any protection to the reputation of the Bank." Certainly, the court went on, it is not afforded the same protection as the reputation of an individual through the law of defamation. While it is would seem right that the Bank of England is a public authority falling within the rule in Derbyshire County Council v Times Newspapers Ltd [1993] AC 534, it does not follow that it has no reputation protected by the law. The House of Lords in the Derbyshire case expressly reserved the possibility of public authorities, although unable to protect their reputation through a civil action for defamation, having their reputations recognised and protected through actions for malicious falsehood; defamation actions by individual employees and officers; and prosecutions for criminal libel.

In the House of Lords, Lord Scott was more forthright. Having concluded that the presentational advice given by Freshfields was "advice as to what should prudently and sensibly be done in the relevant legal context", he went on:

"I would be of the same opinion in relation to presentational advice sought from lawyers by any individual or company who believed himself, herself or itself to be at risk of criticism by an inquiry, whether a coroner's inquest, a statutory inquiry under the 1921 Act or an ad hoc inquiry such as the Bingham Inquiry. The defence of personal reputation and integrity is at least as important to many individuals and companies as the pursuit or defence of legal rights whether under private law or public law (para [44]).”

The test of relative importance to the individual, subjectively measured, is, of course, questionable. If asked which was more "important", many might reply that the protection of confidential communications with a priest, therapist or doctor was more relevant and important to them than those with a lawyer.

Having said that, the conclusion must be right. It has sometimes been considered that, in the balance between the right to free expression and the right to reputation, free expression (guaranteed by Art 10 of the European Convention) must necessarily take priority. The latter is, after all, recognised as a right by the Convention, but only to the extent that it is one of the grounds set out in Article 10 (2) on which the prior right, of freedom of expression, may be limited. That limitation must be restricted to what is "necessary in a democratic society"; and further, it may protect "the rights or reputation of others", suggesting that the latter may not be included in the former.

That position is, at the least, now open to argument. In Radio France v France ECHR 53984/00, 31 June 2004, at para 31, the Strasbourg court underlined that the right to a reputation is part of that bundle of rights which comprises the Article 8 right to respect for a private life. And the domestic courts have now firmly established that in conflicts between these two fundamental rights, there is a delicate balancing exercise to be carried out; there is no presumption that freedom of expression outweighs privacy. (See Campbell v MGN Ltd [2004] UKHL 22, and the pithy 
summary by Lord Steyn in re $S$ (a child) (identification: restriction on publication) [2004] UKHL 47 at para [17]).

In any case, it should be clear that the right to a reputation is a private law right which is capable of forming the subject of litigation; and that legal advice on the protection of that right is therefore privileged.

\section{Legal advice privilege and corporate bodies}

The House of Lords was invited to comment on the decision of the Court of Appeal in Three Rivers (No 5), that only the BIU constituted Freshfields' clients for the purpose of legal advice privilege, and that other employees or ex-employees were to be regarded as third parties such that their communications did not attract privilege. The House carefully refused to be drawn into the question. Lord Scott explained (at para [47]):

"First, the issue is a difficult one with different views, leading to diametrically opposed conclusions, being eminently arguable. Second, there is a dearth of domestic authority. Upjohn Cov United States (1981) 449 US 383 in the United States Supreme Court constitutes a valuable authority in a common law jurisdiction but whether (or to what extent) the principles there expressed should be accepted and applied in this jurisdiction is debatable. Third, whatever views your Lordships may express, and with whatever unanimity, the views will not constitute precedent binding on the lower courts. The guiding precedent on the issue will continue to be the Court of Appeal judgment in Three Rivers (No 5). Fourth, if and when the issue does come before the House (or a new Supreme Court) the panel of five who sit on the case may or may not share the views of your Lordships, or a majority of your Lordships, sitting on this appeal. Fifth, and finally, this House, represented by an Appeal Committee of three, refused leave to appeal against the Three Rivers (No 5) judgment."

This leaves open an important question, particularly for corporate bodies, which can only ever act, or communicate, through employees or officers: when dealing with its legal advisers, what must it do to ensure that communications are privileged? The question - and, ultimately, the correctness of the Court of Appeal decision - remains open to argument.

\section{Litigation privilege}

Litigation privilege was not in issue, as the Bank had always conceded that the Bingham Inquiry was not "litigation". But despite this, Lord Scott picked up on a remark of Lord Phillips MR, to the effect that the policy justification for litigation privilege was readily understood. He went on to comment (at para [29]):

\footnotetext{
"As to the justification for litigation privilege, I would respectfully agree that the need to afford privilege to the seeking or giving of legal advice for the purposes of actual or contemplated litigation is easy to understand. I do not,
}

however, agree that that is so in relation to those documents or communications which although having the requisite connection with litigation neither constitute nor disclose the seeking or giving of legal advice. Communications between litigant and third parties are the obvious example. This House in in re L [1997] AC 16 restricted litigation privilege to communications or documents with the requisite connection to adversarial proceedings. Civil litigation conducted pursuant to the current Civil Procedure Rules is in many respects no longer adversarial. The decision in in re $\mathrm{L}$ warrants, in my opinion, a new look at the justification for litigation privilege. But that is for another day. It does not arise on this appeal."

At a stroke, this introduces potentially massive uncertainty into an area which - the impact of re $L$ aside had been thought to be relatively settled (and had been deliberately left unscathed by the Court of Appeal in its judgments on legal advice privilege). It clearly invites further consideration by the courts of attempts to restrict the scope of litigation privilege, at least in relation to civil proceedings.

\section{CONCLUSIONS}

There is much to be welcomed in the House of Lords decision. The policy basis for legal advice privilege has been restated, and now encompasses the public interest as well as the private interest in the free flow of information and advice between legal adviser and client. The resulting breadth of justification is mirrored in the breadth of the scope of privilege. In asking whether privilege applies to a particular communication, it is not necessary to identify private law rights and obligations such as can become the subject of litigation; it is merely necessary to identify a "relevant legal context" - which is a broad concept.

However, there remain several areas which are pregnant with potential for further satellite litigation. First, it remains to be seen whether the House of Lords has indicated sufficiently clearly the criteria by which practitioners, clients and the courts are to identify a "relevant legal context" to distinguish privileged from nonprivileged communications. Secondly, the detailed oral argument, and the various written interventions, on the dichotomy between a corporate body and its officers and employees for the purposes of legal advice privilege did not move the House to comment on this question. It seems inevitable that, sooner rather than later, this question will fall to be reconsidered. And finally, an invitation has been issued to those wishing to restrict the application of litigation privilege in civil proceedings. (c)

\section{David Willink}

MA (Cantab), LLM; barrister, Middle Temple. The author was the Government's policy adviser responsible for the Attorney General's intervention in the House of Lords proceedings in Three Rivers (No 6), and is now a pupil in Lamb Chambers, Temple. 